\title{
PENGARUH KEMIRINGAN TALANG TERHADAP PERTUMBUHAN DAN HASIL DUA VARIETAS PAKCOY (Brassica rapa L.) DENGAN SISTEM HIDROPONIK NUTRIENT FILM TECHNIQUE
}

\section{THE EFFECT OF GUTTER SLOPE ON GROWTH AND YIELD OF TWO \\ PAKCOY VARIETIES (Brassica rapa L.) WITH NUTRIENT FILM TECHNIQUE HYDROPONIC SYSTEM}

\author{
Syahtian Suprayogi ${ }^{1 \otimes}$ dan Suprihati ${ }^{1}$ \\ ${ }^{1}$ Program Studi Magister Ilmu Pertanian, Fakultas Pertanian dan Bisnis, Universitas Kristen Satya Wacana \\ ${ }^{\square}$ Komunikasi Penulis, email: Syahtiansuprayogi96@gmail.com \\ DOI:http://dx.doi.org/10.23960/jtep-lv10i1.96-103
}

Naskah ini diterima pada 16 Desember 2020; revisi pada 9 Maret 2021;

disetujui untuk dipublikasikan pada 15 Maret 2021

\begin{abstract}
The slope of the gutter affects the dissolved oxygen content in the hydroponic nutrient flow. Dissolved oxygen is one of the factors that can affect plant growth and yield. This study aims to determine the effect of gutter slope on the growth and yield of pakcoy plants. The research was conducted at Jl Pundak Sari, Kutowinangun Kidul, Salatiga, Central Java from March to May 2019 in the greenhouse. Treatment of a combination of green and white pakcoy varieties with a chamfer slope of $6 \%, 9 \%$ and $12 \%$. Each was repeated four times to get 24 experimental units. This study used a randomized block design. The parameters observed were dissolved oxygen, plant height, number of leaves, crown diameter, plant fresh weight. Data were analyzed using variants. To find out the differences between treatments, the DMRT test was used with a 95\% confidence interval Based on the results of the study,bhi the combination of varieties and the slope of the gutter had a significant effect on the number of leaves, crown diameter, and plant fresh weight. The combination of green pakcoy variety with $12 \%$ gutter slope gave the best results including plant height $25.32 \mathrm{~cm}$, number of leaves 18.83, crown diameter $33.36 \mathrm{~cm}$ and fresh weight of $161.4 \mathrm{~g}$ plant-1.
\end{abstract}

Keywords: NFT, varieties, slope gutters, dissolved oxygen

\begin{abstract}
ABSTRAK
Kemiringan talang mempengaruhi kandungan oksigen yang terlarut didalam aliran nutrisi hidroponik. Oksigen terlarut menjadi salah satu faktor yang dapat mempengaruhi pertumbuhan dan hasil tanaman. Penelitian ini bertujuan untuk mengetahui pengaruh kemiringan talang terhadap pertumbuhan dan hasil tanaman pakcoy. Penelitian dilakukan di Jl. Pundak Sari, Kutowinangun Kidul, Salatiga, Jawa Tengah pada bulan Maret hingga Mei 2019 di greenhouse. Perlakuan kombinasi varietas pakcoy green dan white dengan kemiringan talang 6\%, 9\% dan 12\%. Masing-masing diulang empat kali sehingga didapatkan 24 satuan percobaan. Penelitian menggunakan Rancangan Acak Kelompok. Parameter yang diamati oksigen terlarut, tinggi tanaman, jumlah daun, diameter tajuk, berat segar tanaman. Data dianalisis menggunakan sidik ragam. Untuk mengetahui perbedaan antar perlakuan digunakan uji DMRT dengan selang kepercayaan 95\%. Berdasarkan hasil penelitian, kombinasi varietas dan kemiringan talang berpengaruh nyata terhadap jumlah daun, diameter tajuk, dan bobot segar tanaman. Kombinasi varietas green pakcoy dengan kemiringan talang $12 \%$ memberikan hasil terbaik meliputi tinggi tanaman 25,32 $\mathrm{cm}$, jumlah daun 18,83 helai, diameter tajuk 33,36 cm dan berat segar 161,4 $\mathrm{g}$ tanaman $^{-1}$.
\end{abstract}

Kata kunci : NFT, varietas, kemiringan talang, oksigen terlarut

\section{PENDAHULUAN}

Tanaman pakcoy (Brassica rapa L.) merupakan tanaman daun, yang dimana daun tanaman pakcoy diambil daunya untuk dikonsumsi. Dewasa ini tanaman pakcoy banyak dibudidayakan secara hidroponik terutama pada sistem Nutrient Film Technique (NFT). Tanaman 
Pakcoy menjadi komoditi yang diminati oleh pelaku-pelaku hidroponik. Hal ini dikarenakan perawatanya yang mudah, dan waktu panen yang singkat serta harga tanaman pakcoy hidroponik di pasaran cukup tinggi. Gardena, Tosakan, $\mathrm{F}_{1}$ Regency,_Brisk Green, Nauli $\mathrm{F}_{1}$, Green Pakcoy dan White Pakcoy adalah beberapa varietas pakcoy yang sering dibudidayakan secara hidoponik.

Varietas pakcoy yang digunakan ada dua varietas yaitu Green Pakcoy dan White Pakcoy. Penggunaan kedua varietas ini dikarenakan memiliki bobot panen dan waktu panen yang hampir sama sehingga memudahkan pada saat pemanenan dan tidak adanya ketimpangan bobot hasil pada tiap perlakuan. Dalam meningkatkan produktivitas tanaman pakcoy secara hidroponik khususnya NFT ada beberapa aspek yang harus diperhatian antara lain pengelolaan nutrisi dan air, media pertumbuhan, pemilihan komoditas, jenis greenhouse dan talang (Nani dan Rini, 2005).

Kelima aspek tersebut terdapat juga aspek kemiringan talang. Talang adalah tempat lewatnya air nutrisi untuk memenuhi kebutuhan nutrisi tanaman budidaya. Semakin curam kemiringan talang akan meningkatkan debit aliran nutrisi, begitu juga sebaliknya semakin landai kemiringan talang maka debit aliran nutrisi akan melambat. Semakin cepat atau melambatnya aliran nutrisi dialam talang akan berpengaruh terdapat kandungan oksigen terlarut yang terkandung dialam air nutrisi, hal tersebut dikarenakan munculnya riakan air yang timbul pada saat air nutrisi bertabrakan dengan akar tanaman. Semakin bertambahnya usia tanaman maka akar tanaman akan memuhi talang sehingga semakin besar pula riakan air yang terjadi.

Berdasarkan beberapa hasil penelitian yang dilakukan oleh Wibowo et al., (2013), Simbolon, (2011) dan Sibarani, (2005) kemiringan talang mempengaruhi pertumbuhan dan produksi tanaman pada segi panjang akar, bobot segar akar, bobot kering akar, jumlah daun, tinggi tanaman, diameter tajuk, diameter bonggol, bobot segar tajuk, dan bobot kering tajuk. Keberagaman tersebut dikarenakan kemiringan talang berpengaruh terhadap cepat lambatnya aliran nutrisi yang mengalir sehingga mempengaruhi. cepat lambatnya penyerapan unsur hara oleh akar. Serta berpengaruh tebal tipisnya lapisan nutrisi, jika terlalu tipis akan menyebabkan sulitnya penyerapan unsur hara oleh akar namun jika terlalu tebal akan mengakibatkan sulitnya tanaman dalam respirasi (Asmana et al., 2017).

Berdasarkan uraian latar belakang di atas peneliti ingin mengetahui mempraktekan sampai ambang batas mana kemiringan talang berpengaruh terhadap terhadap oksigen terlarut dan pertumbuhan serta produksi dua varietas tanaman pakcoy.

\section{BAHAN DAN METODE}

Penelitian ini telah dilaksanakan pada 25 Maret 2019 di Jl. Pundak Sari, Kutowinangun Kidul, Salatiga. Alat yang diguanakn dalam penelitian ini antara lain; talang trapesium, pipa paralon, telang $\mathrm{PE}$, plastik UV, penyangga talang, netpot, DO meter, EC meter, $\mathrm{pH}$ meter, termometer ruangan dan air, hygrometer, penggaris, bolpoint, meteran, jangka sorong, pompa air, tong nutrisi $A$ dan $B$, tandon air $600 \mathrm{~L}$, timbangan analitik, oven, dan gelas ukur. Bahan yang digunakan dalam penelitian ini antara lain; benih sawi pakcoy, rockwool, nutrisi $\mathrm{AB}$ mix, dan air.

Macam perlakuan dalam penelitian ini adalah $\mathrm{P} 1$ (var. green pakcoy, kemiringan 6\%); P2 (var. white pakcoy, kemiringan 6\%); P3 (var. green pakcoy, kemiringan 9\%); P4 (var. white pakcoy, kemiringan 9\%); P5 (var. green pakcoy, kemiringan 12\%); P6 (var. white pakcoy, kemiringan $12 \%$ ). Terdapat 6 kombinasi perlakuan, dan diulang sebanyak 4 kali, sehingga didapat 24 satuan percobaan. Percobaan ini menggunakan Rancangan Acak Kelompok (RAK). Setap satuan percoban terdiri dari 27 hole, yang digunakan sebagai penelitian adalah 15 hole di tengah. Diambil 10 tanaman secara acak ditengah setiap jalurnya sehingga didapatkan 240 satuan amatan. Parameter yang diamati adalah oksigen terlarut, pertumbuhan tanaman tinggi tanaman (TT), jumlah daun (JD), diameter tajuk (DT), berat segar tanaman (BST). Hasil pengamatan dianalisi menggunakan 
metode sidik ragam uji F 5\%. Untuk mengetahui perbedaan antar perlakuan digunakan uji DMRT (Duncan's Multiple Range Test) dengan selang kepercayaan $95 \%$.

Tahap pelaksanaan pada penelitian ini antara lain: 1. Rockwool dipotong dadu dengan ukuran 2,5 $\mathrm{cm}^{\Xi}$, kemudian disusun diatas tray. rockwool yang sudah disusun kemudian dibasahi air menggunakan spray untuk kemudian dilubangi sedalam $0,5 \mathrm{~cm}$ menggunakan lidi

2. Masukan benih green dan white pakcoy kedalam lubang, setiap satu lubang terdapat satu benih.

3. Didiamkan pada ruang terbuka selama satu hari, setelah benih pecah dormansi kemudian dipindahkan ke talang persemaian dengan EC $0,8 \mathrm{dS} / \mathrm{m}$ sampai tanaman berumur $14 \mathrm{hss}$ (Ifanto dan Suprihati, 2018)

4. Tanaman yang sudah berumur 14 hss kemudian dipindahkan ketalang produksi denga perlakuan kemiringan talang yang berbeda-beda (6\%, $9 \%$ dan $12 \%)$, EC yang digunakan 2,4 dS/m hingga berumur 43 hss. Jarak tanam yang digunakan $20 \mathrm{~cm}$ (Murtiawan et al., 2018)

5. Pemeliharaan tanaman dengan melakukan penyulaman pada tanaman yang mati, menegakan net pot apabila akar tanaman tidak menyentuh aliran air nutrisi, dan melakukan pengendalian hama dan penyakit. Tanaman yang terkena penyakit kaki hitam (Black Leg) akan dibuang dan serangan hama
Plutella xylostella pengendaliannya dilakukan secara manual dengan menggunakan tangan.

6. Pengisian tandon nutrisi tanaman dilakukan 2 minggu sekali (tandon 600L) umur tanaman 1- 21 hss dan pada umur 22- 43 pengisian tandon nutrisi dilakukan seminggu sekali (tandon $600 \mathrm{~L}$ ). Pengurasan air didalam tandon dilakukan 2 minggu sekali untuk menghilangkan lumut yang berada didalam tandon.

\section{HASIL DAN PEMBAHASAN}

Kemiringan talang dan varietas berpengaruh sangat nyata terhadap jumlah daun, nyata terhadap diameter tajuk, bobot segar tanaman, bobot segar bawah dan tidak berpengaruh nyata terhadap tinggi tanaman, diameter batang, panjang akar, bobot segar atas, bobot segar bawah (Tabel 1).

Debit aliran nutrisi diukur pada saat talang perlakuan masih kosong belum diisi dengan tanaman pakcoy. Pengukuran debit aliran nutrisi diukur dari input dan output aliran nutrisi yang masuk dan keluar dari talang perlakuan. Debit aliran yang masuk dan keluar tidak sama dikarenakan jeda waktu dari input dan output tempat keluar air serta kontur permukaan didalam talang yang bergerigi mengakibatkan hambatan air. Pengukuran debit aliran nutrisi dengan menggunakan satuan L/menit. Debit aliran nutrisi dinilai cukup baik, didapatkan debit

Tabel 1. Rekapitulasi Sidik Ragam Pengaruh Kemiringan Talang dan Varietas Terhadap Komponen Pertumbuhan dan Hasil Tanaman Pakcoy pada Umur 43 HSS

\begin{tabular}{lcc}
\hline \multicolumn{1}{c}{ Peubah } & Satuan & F Hitung \\
\hline Tinggi Tanaman & $\mathrm{cm}$ & $0,93 \mathrm{tn}$ \\
Jumlah Daun & helai & $98,15^{* *}$ \\
Diameter Tajuk & $\mathrm{cm}$ & $3,49^{*}$ \\
Diameter Batang & $\mathrm{cm}$ & $1,89 \mathrm{tn}$ \\
Panjang Akar & $\mathrm{cm}$ & $1,11^{\mathrm{tn}}$ \\
Bobot Segar Tanaman & $\mathrm{g}$ & $3,21^{*}$ \\
Bobot Segar Atas & $\mathrm{g}$ & $2,58 \mathrm{tn}$ \\
Bobot Segar Bawah & $\mathrm{g}$ & $3,47^{*}$ \\
Bobot Kering Atas & $\mathrm{g}$ & $0,88 \mathrm{tn}$ \\
Bobot Kering Bawah & $\mathrm{g}$ & $3,56 \mathrm{tn}$ \\
\hline
\end{tabular}

Keterangan: ${ }^{* *}$ berpengaruh sangat nyata uji $\mathrm{F}$ taraf $5 \%$ dan $1 \%,{ }^{*}$ berpengaruh nyata uji $\mathrm{F} 5 \%$, th $=$ tidak berpengaruh nyata 
aliran nutrisi rata-rata 1,51 L/menit, yang dimana debit aliran optimum yang digunakan hidroponik sistem NFT adalah 1-2 L/menit (Setyoadji, 2017). Dari Gambar 1. dilihat bahwa semakin tinggi kemiringan talang maka akan semakin cepat aliran nutrisi, hal ini dibuktikan dengan pada kemiringan $12 \%(\mathrm{P} 5, \mathrm{P} 6)$ interval air masuk dan air keluar lebih sedikit dibandingkan kemiringan 6\% (P1,P2). Hal ini sesuai yang dikatakan Henderson, (1966) apabila kemiringan saluran lebih kecil akan menimbulkan aliran yang lebih lambat, sedangkan jika kemiringan lebih besar maka akan menimbulkan aliran yang lebih cepat.

\subsection{Keragaan Media Nutrisi}

Oksigen terlalut berfungsi untuk proses respirasi aerob di daerah sekitar perakaran, dengan empat tahapan glikolisis (hasil 2 asam piruvat, $2 \mathrm{NADH}$, 2 ATP), dekarboksilasi oksidatif (hasil 2 asetil Co-A, 2 Co 2, 2 NADH), siklus krebs (hasil $4 \mathrm{Co} 2$, 6 NADH 2 FADH2, 2 ATP), transport elektron (hasil 34 ATP, 6 H20), dengan reaksi C6H12O6 +602 -> 6CO2 + 6H2O + 38ATP, proses ini erat kaitannya dengan pembakaran bahan bakar (karbohidrat) berupa makanan menjadi energi yang diperlukan untuk pertumbuhan tanaman.

Hasil Pengamatan oksigen terlarut pada Gambar 2. berkisar antara 7,4-8,1 mg/L. Oksigen terlarut dibutuhkan akar untuk respirasi aerob. Oksigen terlarut juga berperan penting terhadap serapan hara/ nutrisi yang diperoleh dari repirasi akar. Tanpa oksigen yang cukup disekitar akar tanaman tidak dapat menyerap nutrisi dengan optimal. Hubungan antar kadar oksigen yang terlarut dalam air dengan suhu ditunjukan bahwa semakin tinggi suhu maka oksigen yang terkandung didalam air akan semakin berkurang (Effendi, 2003).

Dari Gambar 2. dapat dilihat apabila suhu larutan meningkat maka kandungan oksigen terlarut/ DO pada aliran nutrisi akan menurun, begitu juga sebaliknya apabila suhu larutan nutrisi rendah maka kandungan oksigen terlarut/ DO pada aliran nutrisi akan meningkat. Hal dikarenakan semakin dingin air maka ada proses difusi

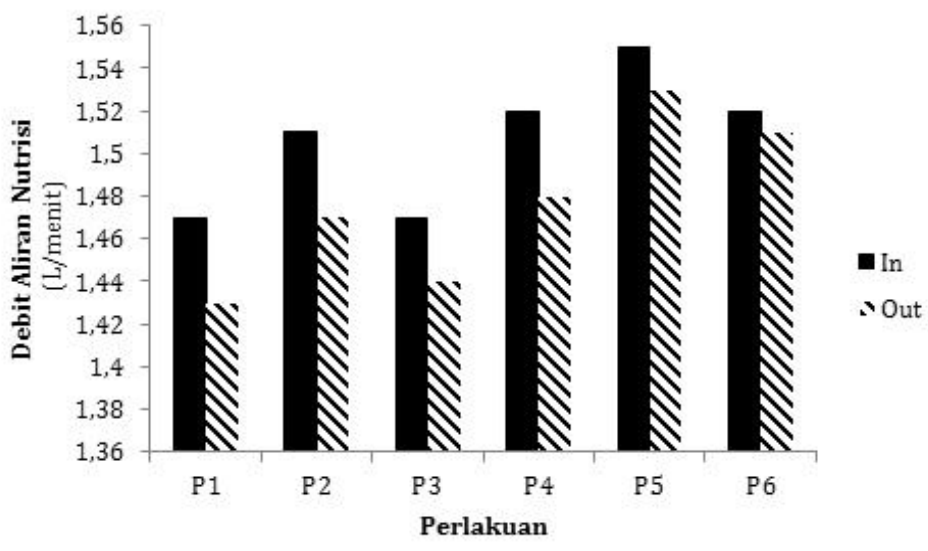

Gambar 1. Pengaruh Perlakuan Terhadap Debit Aliran Nutrisi pada Input dan Output

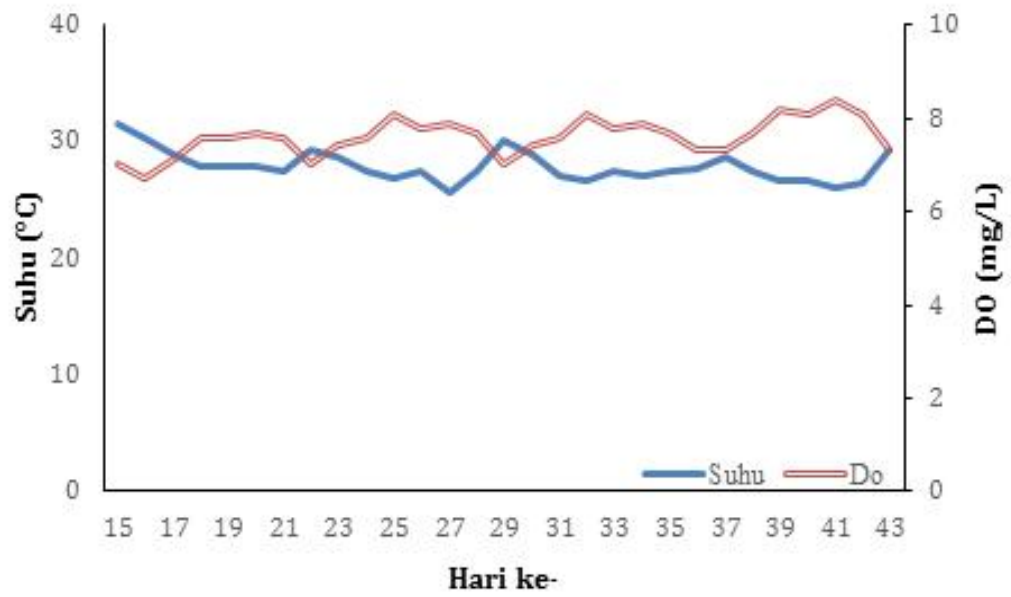

Gambar 2. Grafik Suhu Larutan dan DO (Dissolved Oxygen) Selama Penelitian 
dimana oksigen yang berada di udara memiliki tekana yang lebih tinggi akan berpindah ke air sehingga kandungan oksigen yang terlarut didalam air semakin tinggi (Sarah et al, 2017). Hal ini terjadi dikarenakan adanya proses difusi yang terjadi pada saat oksigen berpindah dari udara ke air atau pun sebaliknya.

Kecepatan difusi oksigen dari udara ke air dipengaruhi beberapa faktor seperti suhu, pergerakan massa air, gelombang dan ketebalan film aliran nutrisi pada talang. Dari Gambar 3. dapat dilihat bahwa kombinasi kemiringan dan varietas mempengaruhi jumlah oksigen terlarut yang terdapat pada aliran nutrisi, DO tertinggi hingga terendah berturut-turut terdapat pada P5 (8,08 mg/L), P6 (8,05 mg/L), P3 (7,78 mg/L), P4 (7,78 mg/L), P1 (7,53 mg/L), P2 (7,58 mg/ L). Dimana semakin miring talang secara tidak langsung akan meningkatkan nilai DO (Dissolved Oxygen) yang terlarut pada aliran perakaran. Sesuai seperti yang dikatakan oleh Sutiyoso, (2004) kemiringan talang akan mengakibatkan riakan pada aliran nutrisi sehingga DO (Dissolved Oxygen) akan meningkat. Dari data Gambar 3. dapat disimpulkan semakin tinggi tingkat kemiringan talang akan mempercepat aliran nutrisi yang mengakibatkan semakin besar riakan yang terjadi sehingga menaikan nilai oksigen yang terlarut dalam aliran nutrisi.

\subsection{Keragaan Pertumbuhan Tanaman}

Komponen pertumbuhan sawi pakcoy meliputi, tinggi tanaman, jumlah daun, diameter tajuk, diameter batang dan panjang akar. Pengukura komponen dilakukan ketika tanaman pindah tanam ke talang produksi pada umur 15 hari setelah semai hingga pada saat panen. Kriteria sawi pakcoy siap panen adalah daun yang tumbuh subur, berwarna hijau segar, pangkal daun tampak sehat, serta ketinggian tanaman seragam atau merata dan tanaman belum menunjukan kefase generatif.

Pertumbuhan tinggi tanaman pada Tabel 2 tidak terlihat perbedaan tinggi antar kedua varietas tanaman pakcoy, dimana green pakcoy memiliki tinggi yang hampir seragam dengan white pakcoy. Pada tahap awal pertumbuhan hingga umur 30 hss tinggi tanaman green pakcoy setiap perlakuan memiliki tinggi yang lebih dominan dibandingkan white pakcoy hal ini dipengaruhi oleh faktor genetik dan pada 40-43 hss pertumbuhan kedua varietas stagnan dengan tidak adanya perbedaan yang nyata antara green pakcoy dan white pakcoy antar setiap perlakuannya, berhentinya pertumbuhan dikarenakan tanaman menuju vase generatif (Lingga, 2003).

Berdasarkan Tabel 2 varietas white memberikan jumlah daun yang saling tidak berbeda nyata pada berbagai kemiringan talang. Jumlah daun ini nyata lebih rendah dibandingkan varietas green. Jumlah daun pada Tabel 2. didapatkan hasil paling baik pada perlakuan P5 (kemiringan talang $12 \%$, varietas green) dengan perolehan jumlah daun 18,83 helai, hasil paling baik selanjutnya terdapat pada perlakuan P3 (kemiringan talang 9\%, varietas green) dengan

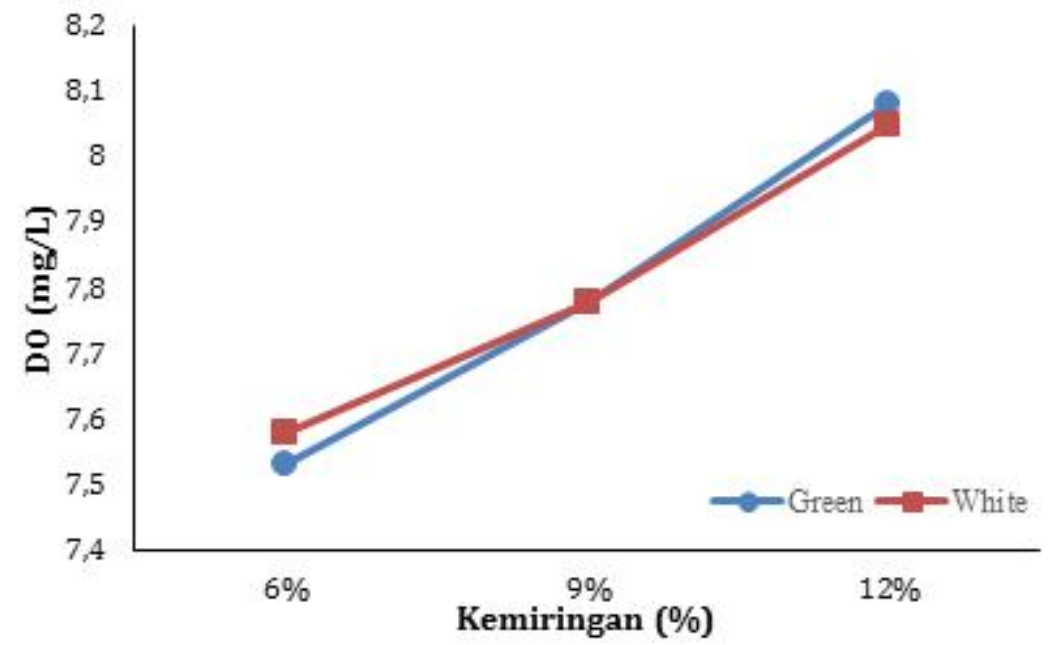

Gambar 3. Grafik Pengaruh Kemiringan Talang terhadap DO (Dissolved Oxygen) pada Dua Varietas Pakcoy Umur 43 HSS 
perolehan jumlah daun 18,00 helai dan disusul P1 (kemiringan talang 6\%, varietas green) dengan perolehan jumlah daun 17,48 helai. Dari Tabel 2. dapat disimpulkan penggunaan sistem hidroponik NFT dengan perlakuan kemiringan talang dapat meningkatkan oksigen yang terlarut didalam lapisan film aliran nutrisi,meningkatnya DO pada aliran nutrisi dipengaruhi oleh semakin miringnya talang hidroponik, namun masih belum diketahui sampai abang batas mana kemiringan talang akan meningkatkan oksigen terlarut. Oksigen terlarut pada Tabel. 2 berpengaruh nyata meningkatkan pertumbuhan tanaman pada variabel jumlah daun. Perbedaan jumlah daun antara kedua varietas dipengaruhi faktor genetik diamana jumlah daun varietas green cenderung lebih banyak dibandingkan varietas white.

Berdasarkan Tabel 2 pada kemiringan 9\% diameter tajuk varietas white nyata lebih tinggi dari pada varietas green. Sedangkan pada varietas lain dengan berbagai kemiringan tidak berbeda nyata. Perbedaan diameter tajuk pada kedua varietas pada kemiringan 9\% diduga diakibatkan daun yang saling berdempetan antar tanaman satu dan lain sehingga daun saling menekan ke bawah. Pada berbagai perlakuan kemiringan diameter tajuk varietas white lebih tinggi dibandingkan varietas green ini dikarenakan tipikal daun varietas white jauh lebih lebar dibandingkan daun varietas green.

Parameter pertumbuhan diameter batang pada Tabel 2 berkisar antara 0,88-0,73 cm, tidak berbeda nyata pada setiap kombinasi perlakuan lainnya. Hal ini tidak sesuai dengan hasil penelitian Kridhianto (2016), yang diamana kemiringan talang berpengaruh nyata terhadap diameter batang tanaman. Hal ini diduga disebabkan oleh jenis tanaman pakcoy yang berbeda yang digunakan dalam penelitian.

Pada parameter pertumbuhan panjang akar pada Tabel 2 berkisar antara 24,87-20,52 cm, tidak berbeda nyata pada tiap kombinasi perlakuan lainnya. Perlakuan P2 (kemiringan talang 6\%, varietas white) memberikan panjang akar tertinggi dibandingkan perlakuan yang lain. Perolehan hasil panjang akar yang tidak berbeda nyata disebabkan akar tanaman yang menumpuk memenuhi ruang pada talang untuk memperoleh serapan nutrisi yang lebih maksimal hal ini dikarenakan sifat akar yang bergerak kearah datangnya air atau aliran air yang paling deras (Endah, 2009) , serta adanya akar yang mengikat akar tanaman lainya dalam satu talang perlakuan.

\subsection{Keragaan Hasil}

Untuk bobot segar atas pada Tabel 3. diperoleh P5 (kemringan talang $12 \%$, varietas green) nyata lebih tinggi dibandingkan P1 (kemiringan talang $6 \%$, varietas green) dan P2 (kemiringan talang $6 \%$, varietas white). Antar perlakuan yang lain saling tidak berbeda nyata. Hal ini terjadi dikarenakan kemiringan talang yang rendah yang mengakibatkan debit aliran nutrisi menjadi lambat sehingga penyerapan unsur hara oleh akar menjadi tidak maksimal. Tingginya bobot segar pada kemiringan talang $12 \%$ diduga diakibatkan timbulnya riakan yang lebih besar

Tabel 2. Pengaruh Berbagai Kemiringan Talang dan Varietas pada Tahap Pertumbuhan

\begin{tabular}{cccccc}
\hline Perlakuan & TT (cm) & JD (helai) & DT (cm) & DB (cm) & PA (cm) \\
\hline 6\% Green (P1) & $24,66 \mathrm{a}$ & $17,48 \mathrm{~b}$ & $30,49 \mathrm{bc}$ & $0,81 \mathrm{a}$ & $20,86 \mathrm{a}$ \\
$6 \%$ White (P2) & $25,45 \mathrm{a}$ & $12,45 \mathrm{c}$ & $30,91 \mathrm{bc}$ & $0,74 \mathrm{a}$ & $24,87 \mathrm{a}$ \\
$9 \%$ Green (P3) & $25,70 \mathrm{a}$ & $18,00 \mathrm{ab}$ & $29,66 \mathrm{c}$ & $0,77 \mathrm{a}$ & $21,67 \mathrm{a}$ \\
$9 \%$ White (P4) & $24,75 \mathrm{a}$ & $12,88 \mathrm{c}$ & $35,05 \mathrm{a}$ & $0,73 \mathrm{a}$ & $24,2 \mathrm{a}$ \\
$12 \%$ Green (P5) & $25,32 \mathrm{a}$ & $18,83 \mathrm{a}$ & $33,36 \mathrm{ab}$ & $0,75 \mathrm{a}$ & $20,52 \mathrm{a}$ \\
$12 \%$ White (P6) & $25,50 \mathrm{a}$ & $13,25 \mathrm{c}$ & $33,47 \mathrm{ab}$ & $0,88 \mathrm{a}$ & $23,09 \mathrm{a}$ \\
\hline
\end{tabular}

Keterangan: TT: Tinggi Tanaman, JD: Jumlah Daun, DT: Diameter Tajuk, DB: Diameter Batang, PA: Panjang Akar. Angka yang diikuti notasi huruf yang sama pada kolom yang sama, tidak berbeda nyata antar perlakuan pada uji DMRT dengan selang kepercayaan 95\% 
Tabel 3. Pengaruh Berbagai Kemiringan Talang dan Varietas pada Tahap Hasil

\begin{tabular}{llllcc}
\hline Perlakuan & BST (g) & BSA (g) & BSB (g) & BKA (g) & BKB (g) \\
\hline 6\% Green (P1) & $126 \mathrm{~b}$ & $101,58 \mathrm{~b}$ & $24,42 \mathrm{~b}$ & $9.07 \mathrm{a}$ & $1,48 \mathrm{~b}$ \\
$6 \%$ White (P2) & $120,9 \mathrm{~b}$ & $95,17 \mathrm{~b}$ & $25,25 \mathrm{~b}$ & $9,15 \mathrm{a}$ & $1,45 \mathrm{~b}$ \\
$9 \%$ Green (P3) & $139,4 \mathrm{ab}$ & $113,42 \mathrm{ab}$ & $26 \mathrm{ab}$ & $8,90 \mathrm{a}$ & $1,53 \mathrm{~b}$ \\
$9 \%$ White (P4) & $146,5 \mathrm{ab}$ & $117,17 \mathrm{ab}$ & $29,33 \mathrm{a}$ & $9,52 \mathrm{a}$ & $1,65 \mathrm{ab}$ \\
$12 \%$ Green (P5) & $161,4 \mathrm{a}$ & $133,00 \mathrm{a}$ & $28,45 \mathrm{ab}$ & $10,37 \mathrm{a}$ & $1,84 \mathrm{a}$ \\
$12 \%$ White (P6) & $147,8 \mathrm{ab}$ & $117,75 \mathrm{ab}$ & $30 \mathrm{a}$ & $10,18 \mathrm{a}$ & $1,84 \mathrm{a}$ \\
\hline
\end{tabular}

Keterangan: BST: Berat Segar Tanaman, BSA: Berat Segar Atas, BSB: Berat Segar Bawah, BKA: Berat Kering Akar,BKB: Berat Kering Bawah. Angka yang diikuti notasi huruf yang sama pada kolom yang sama, tidak berbeda nyata antar perlakuan pada uji DMRT dengan selang kepercayaan 95\%.

daripada kemiringan $6 \%$ pada saat aliran nutrisi melewati akar sehingga oksigen yang terlarut/ dissolved oxygen (DO) pada aliran nutrisi meningkat (Sutiyoso, 2004). Oksigen terlarut didalam aliran nutrisi akan mempermudah kinerja akar tanaman pakcoy untuk berespirasi sehingga energi yang dihasilkan dari respirasi akar tanaman dapat digunakan untuk asimilasi penyerapan air dan nutrisi yang diperlukan untuk pertumbuhan (Jones, 2005). Oksigen terlarut/ dissolved oxygen (DO) yang tinggi akan meningkatan pertumbuhan dan fungsi sel tanaman. Apabila oksigen tidak tersedia dalam aliran perakaran tanaman budidaya berpotensi mengalami hipoksia dan anoksia. Korelasi tinggi tanaman panjang akar

Komponen hasil berat segar tanaman berdasarkan Tabel 3. untuk Bobot Segar Tanaman (BST) pada perlakuan P5 (kemiringan $12 \%$ pada varietas green) memiliki bobot nyata lebih tinggi dibandingkan P1 (kemiringan talang $6 \%$, varietas green dan P2 (kemiringan talang $6 \%$, varietas white), antar perlakuan yang lain saling tidak berbeda nyata. Untuk bobot segar bawah pada Tabel 3. diperoleh P4 (kemiringan talang 9\%, varietas white) dan P6 (kemiringan talang $12 \%$, varietas white) nyata lebih besar dibandingkan P3 (kemiringan talang 9\%, varietas green) dan P5 (kemiringan talang 12\%, varietas green), antar perlakuan yang lain saling tidak berbeda nyata. Peningkatan Bobot Segar Tanama (BST), Bobot Segar Atas (BSA) pada perlakuan P5 dan Bobot Segar Bawah (BSB) pada P6 dipengaruhi oleh besarnya kemiringan talang yang secara tidak langsung meningkatkan debit aliran nutrisi serta oksigen terlarut yang terdapat pada aliran nutrisi sehingga mempermudah proses respiarasi akar sehingga penyerapan air dan nutrisi oleh akar menjadi maksimal sehingga meningkatkan hasil produksi tanaman pakcoy.

\section{KESIMPULAN}

Perlakuan kemiringan talang terhadap pertumbuhan dan hasil pakcoy varietas green dan white berpengaruh sangat nyata terhadap jumlah daun, nyata terhadap diameter tajuk, bobot segar tanaman, bobot segar bawah. Perlakuan kemiringan talang memberian hasil berat segar tanaman tertinggi dan berat segar tanaman rata-rata $161,4 \mathrm{~g}$ dan $140,3 \mathrm{~g}$. Kombinasi varietas green pakcoy dengan kemiringan talang $12 \%$ memberikan hasil terbaik meliputi tinggi tanaman $25,32 \mathrm{~cm}$, jumlah daun 18,83 helai, diameter tajuk 33,36 $\mathrm{cm}$, dan berat segar $161,4 \mathrm{~g}$.

\section{DAFTAR PUSTAKA}

Asmana, M.S., Sirajuddin, H.A., Guyup, M.D.P. 2017. Analisis Keseragaman Aspek Fertigasi Pada Desain Sistem Hidroponik Dengan Perlakuan Kemiringan Talang. Jurnal Ilmiah Rekayasa Pertanian dan Biosistem, 5 (1) : 303-315.

Effendi, H. 2003. Telaah Kualitas Air bagi Pengelolaan Sumberdaya dan Lingkungan Perairan. Kanisius. Yogyakarta

Henderson, F.M. 1966. Open Channel Flow. New York: Macmillan Publising. CO., INC. 
Ifanto, I. dan Suprihati. 2019. Pengaruh EC Saat Pembibitan Terhadap Hasil Sawi (Brassica rapa L.) Metode Hidroponik Sistem Rakit Apung. Jurnal Agritech, 22(2): 118-128.

Jones, Jr., J. Benton. 2005. Hydroponics Apractical Guide For The Soilless Grower Second Edition. Florida : CRC Press.

Kridhianto, R. 2016. Pengaruh Macam Media Tanam dan Kemiringan Talang Terhadap Pertumbuhan dan Produksi Bayam Merah (Amarantus tricolor L.) Pada Sistem Hidroponik NFT. Universitas Muhammadiah Siidoarjo. Sidoarjo

Kusmiyati, Surhayani, F., Karno. 2012. Pengaruh Metode Perbaikan Tanah Salin Terhadap Serapan Nitrogen dan Fosfor Rumput Bengggala (Pacium maximum). Jurnal Animal Agriculture, 1 (2): 168-176

Murtiawan, D., Suasono, H., Agung, N. 2018. Kajian Perbedaan Jarak Tanam dan Umur
Bibit (Transplanting) Pada Tanaman Pakcoy (Brassica rapa .L var chinensis). Jurnal Produksi Tanaman, 6 (2): 264-272.

Sibarani, S.M. 2005. Analisis Sistem Irigasi Hidroponik NFT (Nutrient Film Technique). Universitas Sumatra Utara. Medan

Simbolon, D.R. 2011. Uji Kemiringan Talang Sistem Fertigasi Hidroponik NFT (Nutrient Film Technique) Pada Budidaya Tanaman Sawi (Brassica juncea .L).Universitas Sumatra Utara. Medan

Sutiyoso, Y. 2004. Hidroponik ala Yos. Penebar Swadaya. Jakarta.

Wibowo, S., Arum, A.S. 2013. Aplikasi Hidroponik NFT pada Budidaya Pakcoy (Brassica rapa chinensis). Jurnal Penelitian Pertanian Terapan, 12(3) : 159-167 